\title{
The distribution and host range of Thecaphora melandrii, with first records for Britain
}

\author{
Paul A. Smith ${ }^{1}$ (D), Matthias Lutz ${ }^{2}$ (D) \& Marcin Piątek ${ }^{3}$ (D)
}

Summary. Thecaphora melandrii (Syd.) Vánky \& M.Lutz infects species in the Caryophyllacaeae forming sori with spore balls in the floral organs. We report new finds from Britain, supported by phylogenetic analysis, that confirm its occurrence on Silene uniflora Roth. We review published and web accessible records and note the relatively few records of this smut, its sparse distribution, confined to Europe but scattered predominantly from central to eastern Europe. Analysis of the rDNA ITS and $28 S$ sequences demonstrates little variability among specimens, even those parasitising different host genera, which suggests that the species has evolved relatively recently. Some Microbotryum species infect the same host plants, and we found two species, M. lagerheimii Denchev and M. silenesinflatae (DC. ex Liro) G.Deml \& Oberw., in the same locations as T. melandrii, identified by morphology and molecular phylogenetic analysis. These species may form a stable multi-species community of parasites of Silene uniflora.

Key Words. Caryophyllaceae, gall, Glomosporiaceae, Microbotryum, Silene uniflora, smut.

\section{Introduction}

The Caryophyllaceae is a large family of dicotyledonous plants (Greenberg \& Donoghue 2011), and its species are hosts for many plant-parasitic microfungi, among them at least 38 species of smut fungi assigned to the genera Microbotryum Lév. and Thecaphora Fingerh. (Vánky (2012), with additional species in Denchev et al. (2009); Denchev \& Denchev (2011); Piątek et al. (2012, 2013); Denchev et al. (2019); Kemler et al. (2020)), which form their sori in the floral organs. Although there are similarities in the appearance of the infections and the affected hosts, these two genera are not closely related; Microbotryum is in the Microbotryaceae within the subphylum Pucciniomycotina, and Thecaphora is the only genus in the Glomosporiaceae within the Ustilaginomycotina.

The genus Thecaphora contains plant-parasitic microfungi infecting hosts belonging to a range of dicotyledonous families. The species and their current nomenclature are summarised by Vánky et al. (2008) and Vánky (2012). Recently, three new species were described in Crous et al. (2018), Kruse et al. (2018) and Piątek et al. (in press). Thecaphora species are characterised by having spores in balls (or rarely single), generally without sterile cells, and infections are found in a range of different organs of their host plants. Here we focus on species of Thecaphora infecting hosts in the
Caryophyllaceae, and specifically on T. melandrii (Syd.) Vánky \& M.Lutz. Vánky (2012) lists five species of Thecaphora with hosts in this family, all destroying the inner floral organs; most remain within the outer floral envelope (the calyx), but T. alsinearum (Cif.) Vánky \& M.Lutz also spreads to the uppermost leaves.

Thecaphora melandrii is known to infect Silene latifolia Poir., S. nutans L., S. vulgaris (Moench) Garcke and Stellaria graminea $\mathrm{L}$. as confirmed by genetic analyses of smut specimens from the respective hosts (Vánky \& Lutz 2007; Vánky 2012), and is tentatively reported from several other host species, based on morphological analyses only, although we have traced the sources of only some of these reports below. Some of these tentatively reported hosts are doubtful, and need confirmation. Thecaphora melandrii deforms and partially replaces the inner floral organs, and is therefore gall-forming. The infection remains within the calyx, but causes the buds to deform and remain closed, so that the infection is clearly detectable externally. Here we report recent finds which confirm its occurrence on a new host species (Silene uniflora Roth), based on molecular evidence of nuclear rDNA ITS and 285 sequences, and evaluate its geographical distribution based on published records. Vánky (2012) reported T. melandrii on $S$. vulgaris subsp. maritima (With.) A.Löve \& D.Löve (which is a synonym of $S$. uniflora)

\footnotetext{
Accepted for publication 20 July 2020. Published online 7 October 2020

1 S3RI/Dept of Social Statistics \& Demography, University of Southampton, Highfield, Southampton, SO17 1BJ, UK. e-mail: p.a.smith@soton.ac.uk

2 Plant Evolutionary Ecology, Institute of Evolution and Ecology, University of Tübingen, Tübingen, Germany.

3 W. Szafer Institute of Botany, Polish Academy of Sciences, Kraków, Poland.
} 
but the source of this report is unknown. This fungushost combination was however not verified by molecular methods.

Microbotryum has been found to consist of many similar species, distinguished by DNA sequence analysis and in some cases by subtle morphological differences. Vánky (2012) lists 28 species in hosts of the Caryophyllaceae, including 20 species in the host's anthers. More segregates have been identified subsequently, thus there are now 33 species, including 23 species of so-called anther smuts. Microbotryum anther smut species have co-evolved with their hosts (Refrégier et al. 2008), and are generally strongly host species specific. Several species have been described in recent years throughout the world, but here we consider only some of the European taxa, which have been worked out by Lutz et al. (2005, 2008); Denchev (2007a, b); Le Gac et al. (2007); Denchev et al. (2009); Denchev \& Denchev (2011) and Piątek et al. (2012, 2013).

\section{Materials and Methods}

\section{Specimens}

Specimens used for molecular analyses were of Thecaphora and Microbotryum species infecting Silene uniflora (= S. maritima With., S. vulgaris subsp. maritima), collected in 2019, and preserved by pressing. Specimens were photographed in situ. The collection details are given in Table 1 (Thecaphora) and Table 2 (Microbotryum). The voucher specimens are deposited in the fungarium at the Royal Botanic Gardens, Kew $(\mathrm{K}(\mathrm{M}))$ and in the herbarium of the W. Szafer Institute of Botany, Polish Academy of Sciences, Kraków (KRAM). An example habitat of Silene uniflora where infected individuals were found is shown in Fig. 1.

\section{Morphological analyses}

The morphology of Thecaphora and Microbotryum species were studied using dried specimens. The microscopic characters were analysed by light microscopy (LM), using a Nikon Eclipse 80i light microscope. For this purpose spore balls and spores were placed in $80 \%$ lactic acid, heated to boiling point, cooled and then examined under a light microscope. The spore sizes of Microbotryum specimens were measured using NIS-Elements BR 3.0 imaging software. 30 spores were counted for each collection and the extreme measurements were adjusted to the nearest $0.5 \mu \mathrm{m}$. The species descriptions include the combined values and standard deviation for all measured specimens of the respective species. LM micrographs were taken with a Nikon DS-Fil camera. The morphology of Thecaphora and Microbotryum species are depicted in Figs 2 and 3.
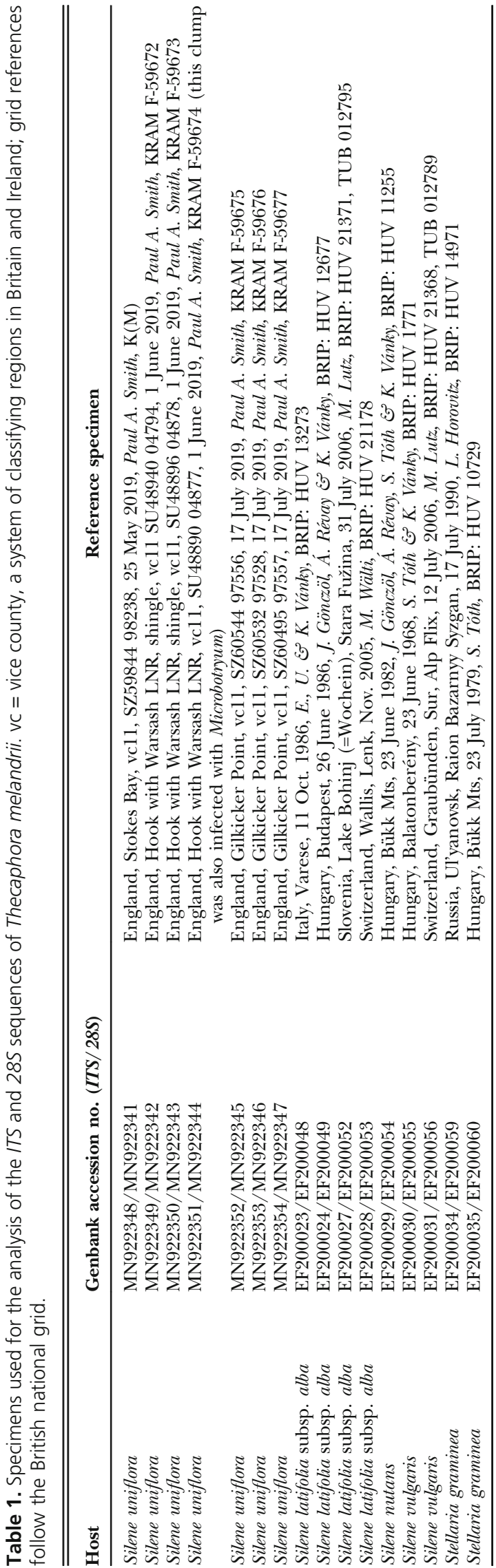
Table 2. Microbotryum specimens from the localities in England searched for Thecaphora melandrii during this study.

\begin{tabular}{|c|c|c|c|}
\hline Species & Host & Genbank accession no. (ITS) & Reference specimen \\
\hline M. lagerheimii & Silene uniflora & MN922355 & $\begin{array}{l}\text { Gilkicker Point, vc11, SZ60334 97729, } 17 \text { July 2019, } \\
\text { Paul A. Smith, KRAM F-59668 }\end{array}$ \\
\hline M. silenes-inflatae & Silene uniflora & MN922356 & $\begin{array}{l}\text { England, Hook with Warsash LNR, vc11, SU48890 04877, } \\
\text { 1 June 2019, Paul A. Smith, KRAM F-59669 } \\
\text { (this clump was also infected with Thecaphora melandrii) }\end{array}$ \\
\hline M. silenes-inflatae & Silene uniflora & MN922357 & $\begin{array}{l}\text { Hayling Island, vc11, SZ71649 98757, } 20 \text { July 2019, } \\
\text { Paul A. Smith, KRAM F-59670 }\end{array}$ \\
\hline M. silenes-inflatae & Silene uniflora & $\mathrm{N} / \mathrm{A}$ & $\begin{array}{l}\text { Hayling Island, vc11, SZ71760 98741, } 20 \text { July 2019, } \\
\text { Paul A. Smith, KRAM F-59671 }\end{array}$ \\
\hline
\end{tabular}

\section{Phylogenetic analyses}

Methods of DNA extraction, PCR, and sequencing of the nuclear rDNA ITS1-5.8S-ITS2 region (ITS) and the nuclear rDNA 28S D1-D2 region (28S) followed Lutz et al. (2004) and Vasighzadeh et al. (2014), and molecular phylogenetic analyses followed the techniques used in Ziegler et al. (2018). To elucidate the phylogenetic position of the Thecaphora specimens their concatenated ITS+28S sequences were analysed along with all the available sequences of T. alsinearum and T. melandrii from GenBank, and three representative specimens of $T$. saponariae (Syd.) Vánky \& M.Lutz. To clarify the relationship of the Microbotryum specimens within the genus Microbotryum, their concatenated ITS $+28 S$ sequences were analysed within datasets covering all the Microbotryum species available in GenBank (data not shown). The GenBank accession numbers of the Thecaphora sequences used and generated in this study are given in Table 1 and Fig. 4, the GenBank accession numbers of the Microbotryum sequences generated in this study are given in Table 2.

A Bayesian inference of the phylogenetic relationships within the sampled Thecaphora specimens was undertaken using Markov chain Monte Carlo analysis of an alignment of the concatenated ITS+28S sequences using the $\mathrm{GTR}+\mathrm{I}+\mathrm{G}$ model of DNA substitution with gamma distributed substitution rates and an estimation of invariant sites, random starting trees and default starting parameters of the DNA substitution model. To illustrate the results, the consensus tree of one run of the Bayesian Approach is presented in Fig. 4. A 50\% majority-rule consensus tree is shown computed from 75,000 trees that were sampled after the process had become stationary. The topology was rooted with the Thecaphora saponariae specimens. Numbers on branches before slashes are estimates for a posteriori probabilities, numbers on branches after slashes are ML bootstrap support values. Branch lengths were averaged over the sampled trees. They are scaled in terms of expected numbers of nucleotide substitutions per site.

\section{Distribution and hosts}

Records of Thecaphora melandrii were sought through an extensive review of the online accessible literature and a selection of European smut floras and checklists, also considering the synonyms (taken from Vánky \& Lutz (2007)) Sorosporium melandrii, So. silenes-inflatae and So. stellariae, and also So. saponariae or T. saponariae only where the host was in Silene L. or Stellaria L. Other online sources (such as online fungarium information, including records from Herbarium Ustilaginales Vánky (HUV; https://collections.daff.qld.gov.au/) and the Solheim Mycological Herbarium) were also investigated. Details of the locations and hosts were abstracted. The distribution of Thecaphora melandrii is shown in Map 1.

\section{Thecaphora melandrii in Britain}

There are many records of Microbotryum spp. from Britain and Ireland recorded in the Fungal Records Database of Britain \& Ireland (FRDBI; http://www.frdbi.info/). They (almost) all infect only the anthers (among species known in Britain \& Ireland (Legon \& Henrici 2005), only M. major on Silene otites (L.) Wibel deforms other floral parts too). So the first author (PAS) was surprised to find several plants of Silene uniflora on the shingle beach at Stokes Bay, Hampshire (see Table 1 for full record details) with deformed, unopened flowers (Fig. 2A, B, D) inside which most of the floral parts were swollen, and there were copious smut spores. The spores were in balls, although held together very loosely and disintegrating easily when mounted on microscope slides. The individual spores were verrucose (Fig. 2C), without the reticulate sculpturing characteristic of most Microbotryum species. This was clearly Thecaphora melandrii, which is not included in Legon \& Henrici (2005) or its updates, and is therefore the first record for Britain \& Ireland. Infected plants were present along approx. $1 \mathrm{~km}$ of the beach.

Further searching showed Thecaphora melandrii to be frequent infecting Silene uniflora on shingle at Hook with Warsash (SU4804), approx. $11 \mathrm{~km}$ from the Stokes Bay location, but it could not be found in searches on Hayling Island to the east of Stokes Bay. Nevertheless, it seems possible that $T$. melandrii may be in further suitable places along the south coast of England. All the searched locations had S. uniflora 


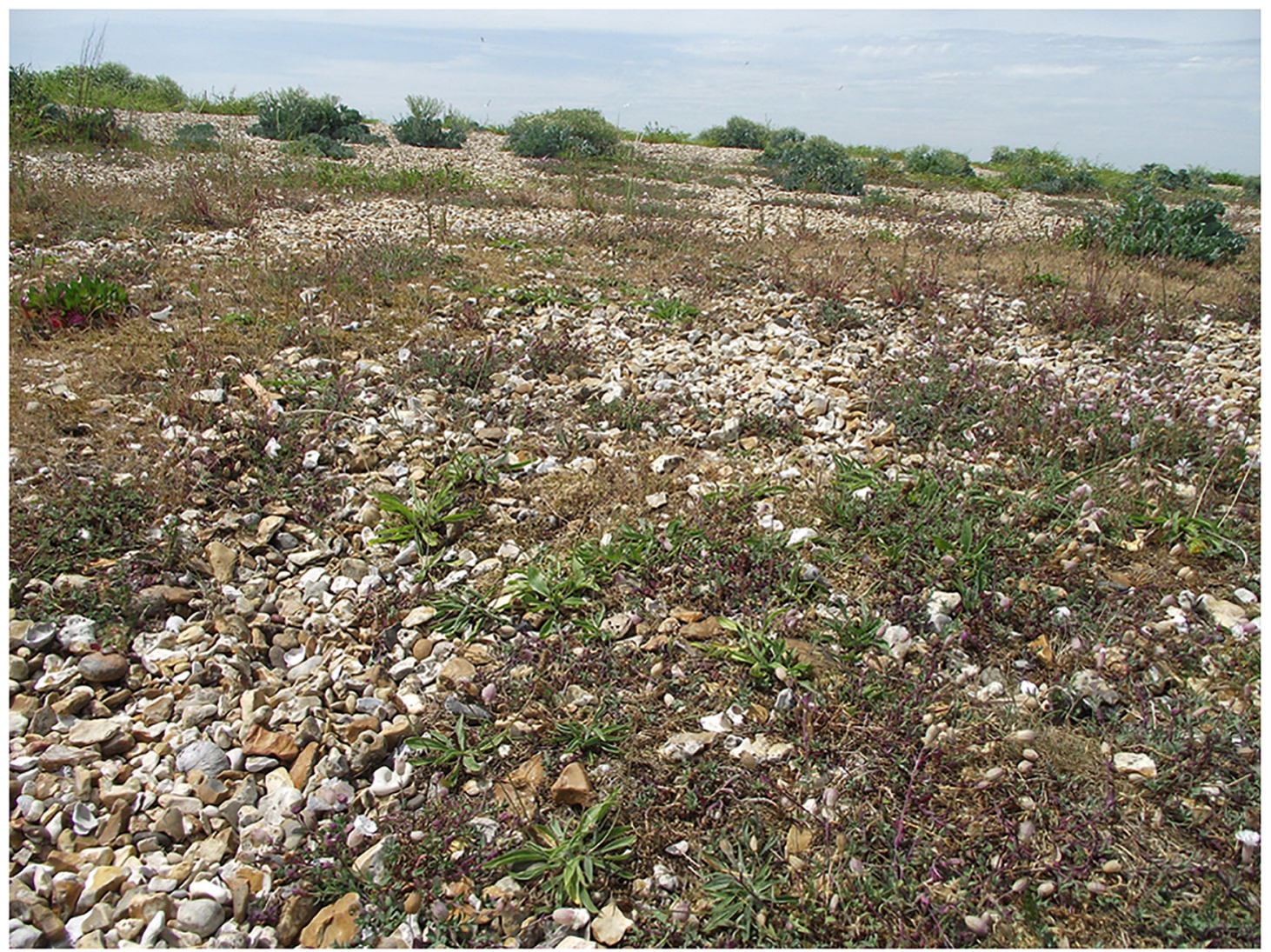

Fig. 1. Habitat of Silene uniflora (in the foreground) infected with Thecaphora melandrii at Hook with Warsash; the large plants in the background are Crambe maritima.

plants with anthers infected by Microbotryum sp., and we return to these under Microbotryum species below.

The habitat in both locations (for a habitat example see Fig. 1) consists of stable shingle beaches with sparse vegetation consisting of Beta vulgaris L. subsp. maritima (L.) Arcang., Crambe maritima L., Glaucium flavum Crantz, Plantago lanceolata L. and Silene uniflora; this belongs to the Rumex crispusGlaucium flavum shingle community (National Vegetation Classification SD1 (Rodwell et al. 2000: 128 132)). Silene uniflora is frequent in this habitat, which may help T. melandrii to persist in relative abundance.

Several observations suggest further details of the life cycle of Thecaphora melandrii. In most infected clumps of its host, every flower is infected (Fig. 2A, E, F), which suggests that the infection is systemic. Occasionally there are a few uninfected flowers in a clump, and then it is unclear whether some flowers are able to escape infection and develop normally, or whether the clump contains more than one individual of the host. One host clump at Hook with Warsash was infected with both T. melandrii and Microbotryum silenes-inflatae (Fig. 2E, Microbotryum species below); it appeared that this was a single plant, but the possibility of two individuals growing together cannot be ruled out.
Although all the parts of flowers within the calyx are normally infected and swollen (Fig. 2D), occasional flowers on infected plants still produce exserted corollas (Fig. 2F), and the same phenomenon was reported by Kruse et al. (2020). So there seems to be some variation in infection intensity even within a host plant.

Silene uniflora is regularly robbed for its nectar by insects (presumably short-tongued bees, although this was not observed) which drill holes in the calyx. The same sort of holes were observed in some of the flowers infected by Thecaphora melandrii (Fig. 2F), and this suggests a mechanism for infections to spread to new hosts, since infected flowers do not otherwise open. A reviewer noted similar holes on infected specimens of S. latifolia subsp. alba (Mill.) Greuter \& Burdet, possibly made by caterpillars. Spores are also exposed as the flowers senesce, and could also be wind-distributed.

The ITS and 28S sequences extracted from the specimens from southern England were compared with all the available sequences for Thecaphora melandrii, the latter included in the analysis of Thecaphora species on caryophyllaceous hosts by Vánky $\&$ Lutz (2007). Details of the collections and accession 


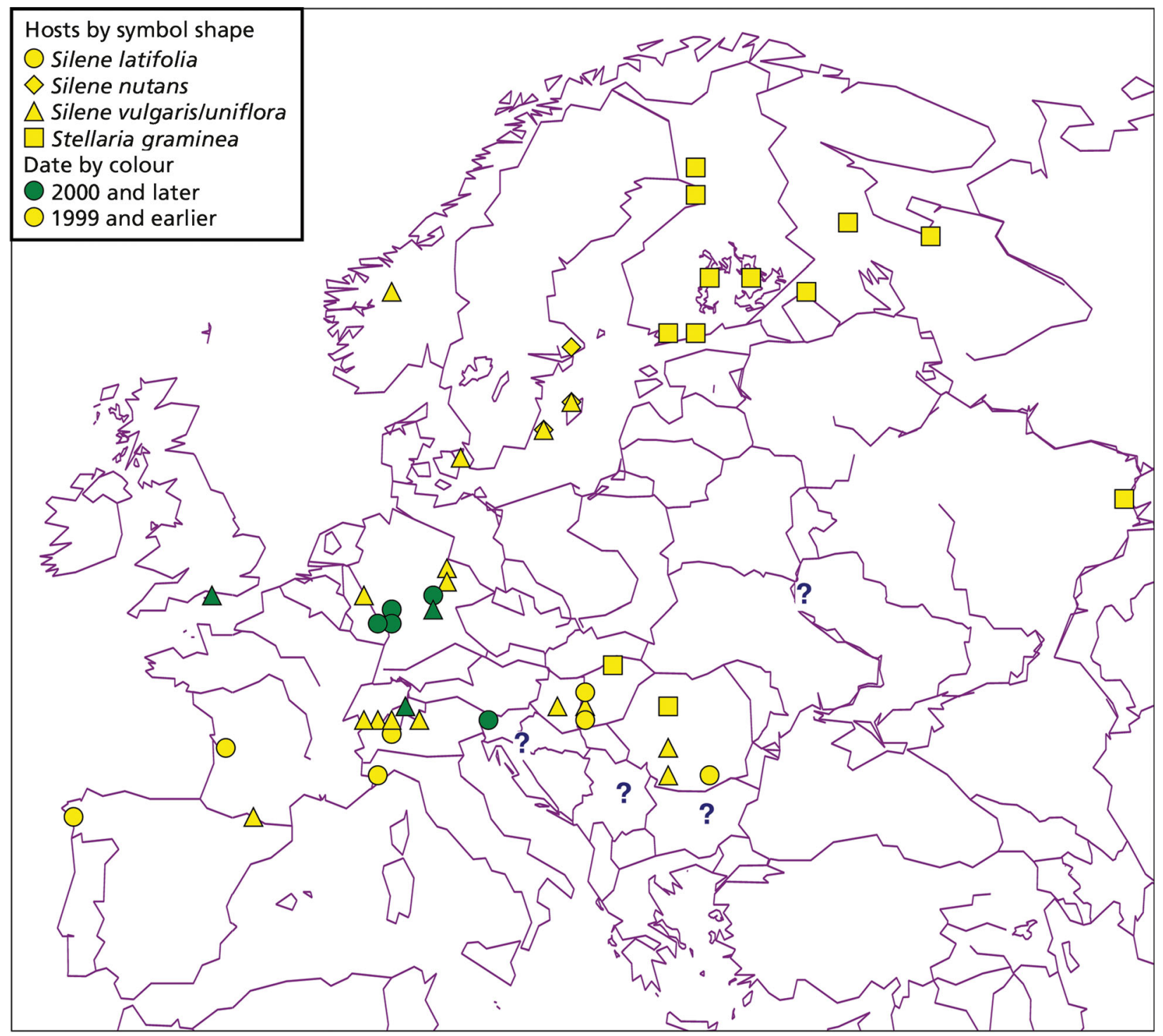

Map 1. Known distribution of Thecaphora melandrii. Green symbols denote records made since 2000, and yellow symbols records made before 2000. Different symbol shapes denote infections of different hosts (sometimes superimposed). '?' denotes vaguely localised records. Map produced with DMAP.

numbers are given Table 1. No further sequences for T. melandrii were available in GenBank.

A Bayesian inference of the phylogenetic relationships within the sampled Thecaphora specimens is shown in Fig. 4. The ITS and $28 S$ sequences are remarkably homogenous, with almost no differences. This is surprising, given that it infects several different host species across two genera; of course there may be differences in other areas of the genome, but on the evidence in ITS and $28 \mathrm{~S}$ it looks as if this is a recently evolved species, so that there has been insufficient time for divergence of the ITS and $28 S$ sequences; this would also suggest that a single pathogen is involved in infecting these host species. It would be worthwhile undertaking artificial infection experiments to confirm that $T$. melandrii does not vary in its infection ability on different hosts.
The lack of differences confirms that the specimens from England are consistent with the species concept for T. melandrii, and this also confirms the tentative assignment of Silene uniflora as a host by Vánky \& Lutz (2007).

\section{Microbotryum species}

The localities searched for Thecaphora melandrii also supported Microbotryum specimens, and the morphology as well as the rDNA ITS and $28 S$ sequences for these collections were also examined. The collection details are given in Table 2. According to our molecular phylogenetic analyses, the clump with infections of both T. melandrii and Microbotryum sp. at Hook with Warsash was infected by M. silenes-inflatae, 

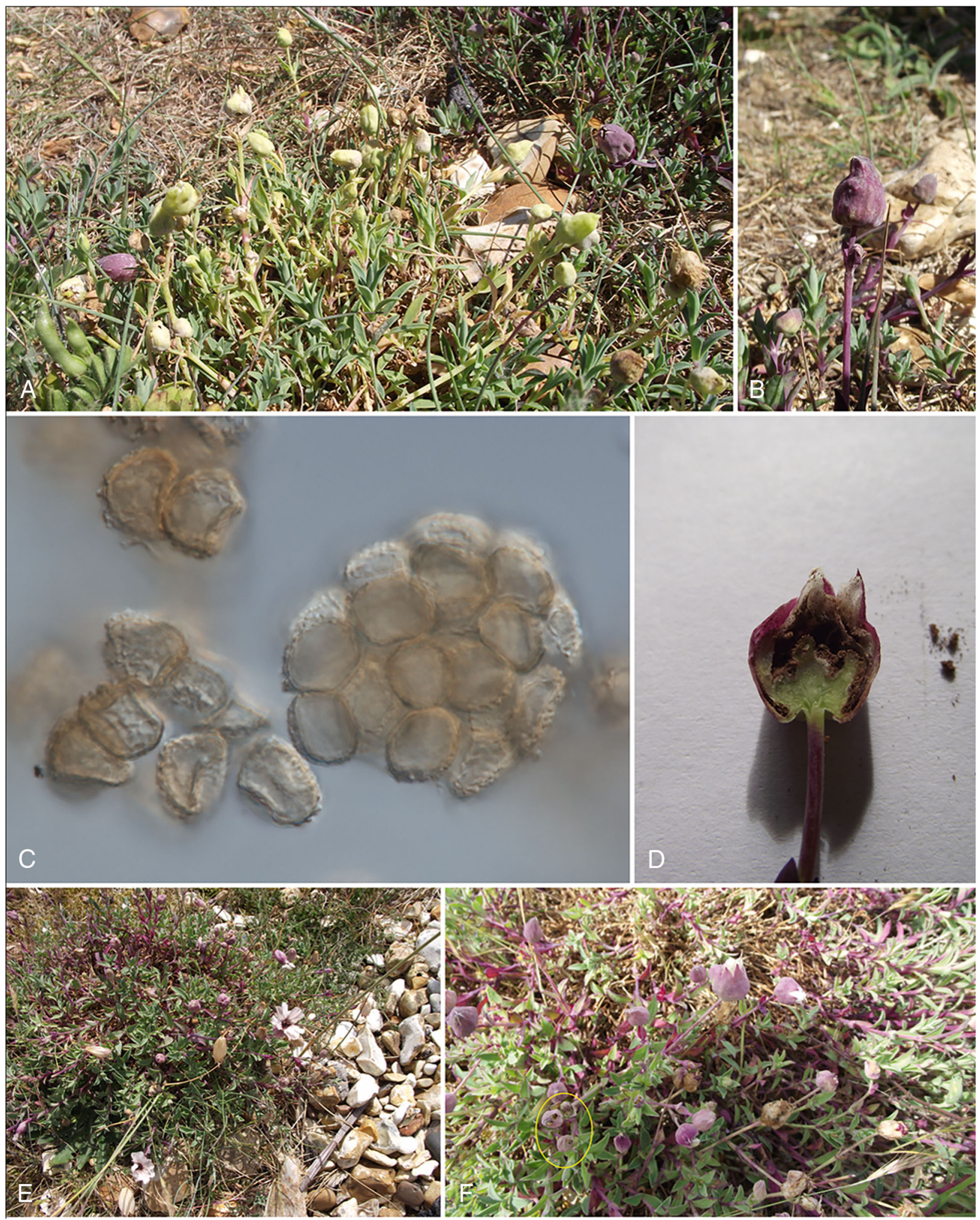

Fig. 2. A Silene uniflora plants infected by Thecaphora melandrii showing the deformed, unopened flowers. Note that all flowers in a clump are infected. B close-up of infected head (note that S. uniflora has forms with and without anthocyanins (Marsden-Jones \& Turrill 1957: 289 - 298), which is why there is a difference in the colours). C spore balls, seen by LM, showing the verrucose sculpturing of the spores in contrast to the reticulate pattern on spores of most Microbotryum spp.; D section through infected flower showing the swollen inner floral parts; E single clump of S. uniflora infected with T. melandrii and Microbotryum silenes-inflatae; F infected plant with some infected flowers (e.g., upper right) showing corollas, some infected flowers (circled) have holes in their calyces where insects have attempted to rob them for nectar. 
and the other site for T. melandrii at Gilkicker Point produced M. lagerheimii. At Hayling Island where no Thecaphora spp. infection was found, the anther smut was $M$. silenes-inflatae. The morphology showed differences between the two species detected by molecular analyses. The sori of $M$. lagerheimii in host anthers were light violaceous, spores were pale violet in transmitted light, globose, subglobose, to broadly ellipsoid, $5.0-7.5 \times$ $5.0-6.5(-7.0) \mu \mathrm{m}$ [av. $\pm \mathrm{SD}, 6.3 \pm 0.7 \times 5.9 \pm 0.6 \mu \mathrm{m}, n=$ $30 / 1]$; the wall was reticulate, c. $0.5-1.0 \mu \mathrm{m}$ high, the meshes were more or less polyhedral, usually irregular, and the number of meshes per spore diameter was $5-8$. The sori of $M$. silenes-inflatae in host anthers were relatively dark violaceous, spores were pale violet or violet in transmitted light, globose, subglobose, to broadly ellipsoid, $6.0-8.5(-9.5) \times(5.5-) 6.0-7.5(-$ 8.5) $\mu \mathrm{m}$ [av. \pm SD, $7.4 \pm 0.8 \times 6.8 \pm 0.6 \mu \mathrm{m}, n=90 / 3$ ]; the wall was reticulate, c. $0.8-1.3 \mu \mathrm{m}$ high, the meshes were more or less polyhedral, usually irregular, and the number of meshes per spore diameter was $6-9$. The second specimen from Hayling Island, not investigated by molecular methods, could be identified as $M$. silenesinflatae based on morphology. Microbotryum lagerheimii and M. silenes-inflatae are differentiated based on the colour of the sori (pale violaceous vs dark violaceous) and average of spore sizes $(<7 \mu \mathrm{m}$ vs $>7 \mu \mathrm{m})$ (Fig. 3). This morphology is consistent with data of Denchev (2007a) for both species and Smith et al. (2017) for M. silenesinflatae in the Outer Hebrides. Chung et al. (2012) have already shown that there are sympatric populations of these two Microbotryum species in southern England, so the sites are not necessarily differentiated by these records. By contrast, in the northern part of the UK, in the Outer Hebrides, only M. silenes-inflatae has so far been found on Silene uniflora (Smith et al. 2017). Abbate et al. (2018) show that different Microbotryum spp. occur widely in low- and high-altitude populations of $S$. uniflora and $S$. vulgaris. Nevertheless, it is clear from our limited records and previous research that populations of any pair of these three species of smut found in this study are able to co-exist in a site, even though they share a host and a similar niche. Further sampling is needed to examine whether all three parasite species can form a stable system.

\section{Distribution and scarcity of Thecaphora melandrii} Table 3 lists all of the records (worldwide) for Thecaphora melandrii which we traced in our literature search (excluding those already listed in Table 1 and doubtful records in Table 4).

\section{Biogeography}

In total there are 90 published and herbarium records, and because there are some duplicate collections, even fewer localities. Records based only on the online catalogue of HUV contain at most country-level infor- mation. There are undoubtedly collections which have not been published, and some, particularly earlier, collections may be under names which applied to multiple species under current taxonomic concepts, and therefore are not clearly identifiable as Thecaphora melandrii. Nevertheless, it seems that this is a scarce species, with few records anywhere; several authors comment specifically on its scarcity (Sydow 1934; Liro 1938; Lindeberg 1959). There has been a surge in recent records, particularly a clutch of records from Germany (Kruse et al. 2015, 2017, 2020), probably as result of renewed interest in smuts (but possibly also affected by changes in the publication of records), but the number of recent records is still small by contrast with Microbotryum spp. The records of T. melandrii are mapped in Map 1. Thecaphora melandrii is apparently restricted to Europe, although there are eastern European records from Russia and Ukraine, which suggests that the species may yet be found in Asia, and there is a report from Kazakhstan (Schwartzman 1962, Table 4), although on a host species which requires further evidence to assess whether the smut belongs to this species rather than to another host species-specific taxon. Similarly, reports from America (see Table 4) are not clearly referable to this species without further evidence.

The most recent records from England are notable in being coastal; many of the remaining records (where there is sufficient detail to make an assessment) are inland (although there are also coastal records from Sweden), and largely in continental climates. This is despite the occurrence of its hosts in a wide range of habitats. The English locations are therefore in quite a different habitat type, and show that Thecaphora melandrii potentially has a wide biogeographical range and should be sought in further locations.

Since we have well-founded information on the recorded distribution we are able to make a provisional assessment for Thecaphora melandrii against the IUCN red list criteria. There is some evidence of decline in the area occupied as shown by recent records (Map 1), but we strongly suspect that this a result of fluctuation in recording rather than fluctuation in the occurrence of $T$. melandrii. There are many individuals (systemically infecting plants of the hosts) in each locality, so the total population of mature individuals is likely to be large. Finally, no specific threats have been identified. We therefore provisionally suggest that this species should be classified as LC least concern.

\section{Host range}

Thecaphora melandrii has been found infecting Silene vulgaris, S. uniflora, S. latifolia and S. nutans, and Stellaria graminea. The first three Silene species are quite closely related (particularly S. uniflora and S. vulgaris) (Greenberg \& Donoghue 2011, Fig. 1), but $S$. nutans is more distantly related within the 

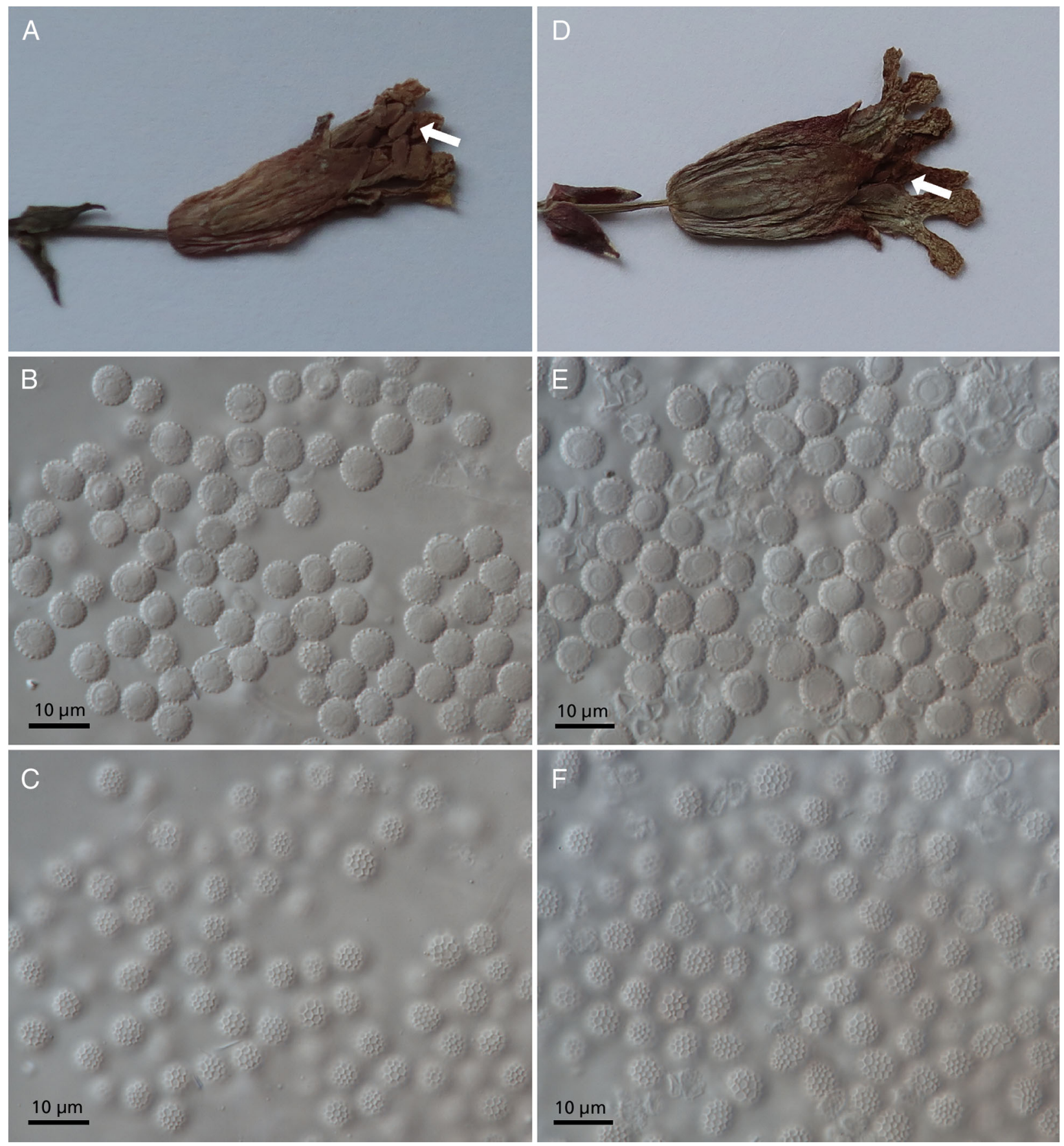

Fig. 3. Microbotryum lagerheimii: A sori in anthers shown by arrow; spores, seen by LM, in B median and C surface views; M. silenes-inflatae: $\mathbf{D}$ sori in anthers shown by arrow; spores, seen by LM, in $\mathbf{E}$ median and $\mathbf{F}$ surface views.

many species in the genus Silene. The infection of Stellaria graminea is perhaps more surprising, as it is considerably more distantly related to Silene (Greenberg \& Donoghue 2011, Figs 2, 4, 5). Liro (1938) records $T$. melandrii on Stellaria graminea from a range of sites scattered across Finland and nearby parts of Russia, and there is a further cluster of records on this host from Romania in HUV. The minimal variation in the DNA from
T. melandrii on any of these hosts suggests that it is a single taxon with the ability to infect a range of host species. Infection of further species might therefore also be possible; however, other species of Silene are also infected by segregate species (such as T. italica M.Lutz \& Vánky on Silene italica (L.) Pers.).

Table 4 lists infections on a small number of additional hosts which could represent Thecaphora 
Table 3. Literature and web-accessible records of Thecaphora melandrii (records from Table 1 are not repeated).

\begin{tabular}{|c|c|c|c|c|}
\hline Country & Location & Host & Source & Date \\
\hline ? & & Silene vulgaris & HUV1764 & July 1920 \\
\hline ? & & Silene vulgaris & HUV5677 & 6 Aug. 1972 \\
\hline ? & & Stellaria graminea & HUV8851 & 6 July 1961 \\
\hline ? & & Stellaria graminea & HUV1779 & 10 July 1968 \\
\hline ? & & Stellaria graminea & HUV1780 & 12 July 1968 \\
\hline ? & & Stellaria graminea & HUV10785 & 4 July 1982 \\
\hline Bulgaria & & Silene latifolia & HUV1744 & June 1885 \\
\hline Croatia & & Silene vulgaris & Ivić et al. (2013) & 1916 \\
\hline Denmark & Lyngby, Seeland & Silene vulgaris & Lind (1913), ?HUV1761 & ?4 July 1912 \\
\hline Finland & Jyväskylä, Harju, Torikatu & Stellaria graminea & $\begin{array}{l}\text { Liro (1938), Vánky \& } \\
\quad \text { Lutz (2007), HUV1772 }\end{array}$ & 7 July 1913 \\
\hline Finland & Ab: Lohja, Lylyis & Stellaria graminea & Liro $(1938)$ & 13 July 1904 \\
\hline Finland & $\mathrm{N}$ : Pornainen, Laha & Stellaria graminea & Liro (1938) & July 1903 \\
\hline Finland & N: Tuusula, Järvenpää & Stellaria graminea & Liro (1938) & July 1916 \\
\hline Finland & Kl: Impilahti, Hippola & Stellaria graminea & Liro (1938) & 23 June 1915 \\
\hline Finland & Sb: Joroinen, Koskenkylä & Stellaria graminea & Liro (1938), HUV16940 & 20 July 1918 \\
\hline Finland & Kpocc: Sjuigarvi & Stellaria graminea & Liro $(1938)$ & 15 July 1896 \\
\hline Finland & Kpor: Vorsogor, nr Onega town & Stellaria graminea & Liro (1938) & 28 July 1899 \\
\hline Finland & $\begin{array}{l}\text { Ob: Oulu, Merikoski, } \\
\text { by the bridge }\end{array}$ & Stellaria graminea & Liro (1938) & 28 June 1928 \\
\hline Finland & $\begin{array}{l}\text { Ob: Tervola, } \\
\text { Keminjoki, Pallinoja }\end{array}$ & Stellaria graminea & Liro (1938) & 3 Aug. 1933 \\
\hline France & Chateau Eyquem & Silene latifolia & Dauphin (1993) & 4 July 1993 \\
\hline Germany & Rheinland, Köln-Zollstock & Silene latifolia & Vánky \& Lutz (2007) & 29 Sept. 1932 \\
\hline Germany & Rheinland, Köln-Zollstock & Silene latifolia & $\begin{array}{l}\text { Ustilagineen Europas \#129, } \\
\text { Vánky \& Lutz (2007), } \\
\text { HUV1746, HUV9788, } \\
\text { HUV10815 }\end{array}$ & 21 June 1934 \\
\hline Germany & Rheinland, Köln-Zollstock & Silene latifolia & $\begin{array}{l}\text { Solheim Mycological } \\
\text { Herbarium }\end{array}$ & 16 July 1935 \\
\hline Germany & $\begin{array}{l}\text { Rheinland, Köln-Zollstock, } \\
\text { Sand Pit on the Gottesweg }\end{array}$ & Silene latifolia & & 14 June 1937 \\
\hline Germany & $\begin{array}{l}\text { Hessen, Hattersheim } \\
\text { am Main }\end{array}$ & Silene latifolia subsp. alba & Kruse et al. (2017) & 15 Oct. 2016 \\
\hline Germany & $\begin{array}{l}\text { Hessen, Frankfurt am } \\
\text { Main, Oberrad, N of } \\
\text { Offenbacher Landstraße, } \\
\text { fields S of Buchrain, } \\
\text { embankment }\end{array}$ & Silene latifolia subsp. alba & Kruse et al. (2015) & 3 Nov. 2013 \\
\hline Germany & $\begin{array}{l}\text { Hessen, Main-Taunus-Kreis, } \\
\text { Flörsheim/Main, } \\
\text { Hochgewann, } \\
\text { meadows by railway }\end{array}$ & Silene latifolia subsp. alba & Kruse et al. (2015) & 10 May 2014 \\
\hline Germany & $\begin{array}{l}\text { Hessen, Main-Taunus-Kreis, } \\
\text { Wiesbaden: } \\
\text { Ginsheim-Gustavsburg, } \\
\text { main cycle path, dyke }\end{array}$ & Silene latifolia subsp. alba & Kruse et al. (2015) & 17 May 2014 \\
\hline Germany & $\begin{array}{l}\text { Hessen, Main-Taunus-Kreis, } \\
\text { Flörsheim/Main, main road, } \\
\text { meadow at sports club }\end{array}$ & Silene latifolia subsp. alba & Kruse et al. (2015) & 27 July 2014 \\
\hline Germany & Saxony, Eisleben & Silene vulgaris & $\begin{array}{l}\text { Örtel (1886), Săvulescu } \\
\text { (1957), Vánky \& } \\
\text { Lutz (2007), ?HUV1760 }\end{array}$ & 1875 \\
\hline Germany & $\begin{array}{l}\text { Bottendorfer Schachtberg, } \\
\text { between Bottendorf } \\
\text { and Rossleben }\end{array}$ & Silene vulgaris & Örtel (1886) & c. 1875 \\
\hline Germany & Ahrtal & Silene vulgaris & Niessen (1937) & $\leq 1937$ \\
\hline Germany & Bonn & Silene vulgaris & Niessen (1937) & $\leq 1937$ \\
\hline Germany & Rodderberg & Silene vulgaris & Niessen (1937) & $\leq 1937$ \\
\hline Germany & $\begin{array}{l}\text { Bayern, Oberfranken, Lkr. } \\
\text { Haßberge, S of Hassfurt }\end{array}$ & Silene vulgaris & Kruse et al. (2017) & 28 July 2016 \\
\hline Germany & $\begin{array}{l}\text { Bayern, Oberfranken, } \\
\text { Lkr. Lichtenfels, c. } 2.7 \mathrm{~km} \\
\text { WSW of Bad Staffelstein }\end{array}$ & Silene vulgaris & Kruse et al. (2017) & 10 Aug. 2016 \\
\hline Germany & $\begin{array}{l}\text { Bayern, Oberfranken, } \\
\text { Lkr. Lichtenfels, c. } \\
2 \text { km N of Zapfendorf }\end{array}$ & Silene vulgaris & Kruse et al. (2017) & 18 Aug. 2016 \\
\hline
\end{tabular}




\begin{tabular}{|c|c|c|c|c|}
\hline Germany & $\begin{array}{l}\text { Rheinland-Pfalz, Lkr. } \\
\text { Mainz-Bingen, Ingelheim: } \\
\text { c. } 1.3 \mathrm{~km} \mathrm{E} \mathrm{of} \mathrm{Gau-Algesheim}\end{array}$ & Silene latifolia subsp. alba & Kruse et al. (2020) & 14 May 2017 \\
\hline Germany & $\begin{array}{l}\text { Thüringen, Lkr. Gotha, } \\
\text { c. } 2.5 \mathrm{~km} \text { SSW of Wandersleben }\end{array}$ & Silene latifolia subsp. alba & Kruse et al. (2020) & $\begin{array}{l}\text { many collections } 13 \\
\text { June } 2017- \\
\text { 26 Aug. } 2019\end{array}$ \\
\hline Hungary & & Silene latifolia & HUV1743 & 26 May 1881 \\
\hline Hungary & & Silene latifolia & HUV1745 & 31 May 1905 \\
\hline Hungary & Nemesnáduvár & Silene latifolia & Săvulescu (1957) & 1928 \\
\hline Hungary & Budapest & Silene latifolia & Săvulescu (1957), ?HUV8096 & 14 June 1934 \\
\hline Hungary & & Silene vulgaris & HUV8602 & Aug. 1916 \\
\hline Hungary & & Silene vulgaris & HUV1765, HUV1767 & 21 June 1922 \\
\hline Hungary & Foktö, Pest county & Silene vulgaris & Béla (1924) & 1924 \\
\hline Italy & $\begin{array}{l}\text { Alassio, on the old Roman } \\
\text { road S of Croce-Albenga, } \\
\text { NE S. Anna }\end{array}$ & Silene latifolia & $\begin{array}{l}\text { Petrak (1970), } \\
\text { HUV12868, HUV6086 }\end{array}$ & 27 May 1969 \\
\hline Norway & Röysheim, Lom & Silene vulgaris & Săvulescu (1957), Jørstad (1963) & 1894 \\
\hline Romania & $\begin{array}{l}\text { Bucharest, Cotraceni } \\
\text { Botanical Garden }\end{array}$ & Silene latifolia & $\begin{array}{l}\text { Săvulescu (1957), } \\
\quad \text { Herbarium Mycologicum } \\
\text { Romanicum Fasc XXIX } \\
\text { Nr. 1437, HUV1747 }\end{array}$ & 26 May 1949 \\
\hline Romania & Bucharest, Herästräu & Silene latifolia & Săvulescu (1957) & 10 May 1926 \\
\hline Romania & & Silene latifolia & HUV10646, HUV11254 & 27 May 1981 \\
\hline Romania & Polovraci & Silene vulgaris & Săvulescu (1957), HUV12767 & 28 June 1938 \\
\hline Romania & Parcul Poporului, Craiova & Silene vulgaris & Săvulescu (1957) & 21 Sept. 1954 \\
\hline Romania & Muntele Baisoara & Stellaria graminea & Săvulescu (1957), HUV1773 & 10 June 1953 \\
\hline Romania & & Stellaria graminea & HUV1774 & 5 July 1964 \\
\hline Romania & & Stellaria graminea & $\begin{array}{l}\text { HUV1775, HUV1776, } \\
\text { ?HUV8791 }\end{array}$ & 2 Aug. 1964 \\
\hline Romania & & Stellaria graminea & HUV1777 & 10 July 1966 \\
\hline Romania & & Stellaria graminea & HUV1778 & 4 July 1968 \\
\hline Romania & & Stellaria graminea & HUV1781 & 13 Aug. 1973 \\
\hline Romania & & Stellaria graminea & HUV12869 & 29 June 1974 \\
\hline Romania & & Stellaria graminea & HUV10675 & 5 July 1981 \\
\hline Romania & & Stellaria graminea & HUV11096 & 12 Aug. 1982 \\
\hline Serbia & & Silene vulgaris & HUV1769 & 14 May 1952 \\
\hline Slovenia & $\begin{array}{l}\text { Lake Bohinj, } \\
\text { Stara Fužina, meadow } \\
\text { close to Studor }\end{array}$ & Silene latifolia subsp. alba & Lutz \& Vánky (2009) & 31 July 2006 \\
\hline Spain & $\begin{array}{l}\text { Santiago de } \\
\text { Compostela and Padrón }\end{array}$ & Silene latifolia & $\begin{array}{l}\text { Losa España (1942); } \\
\text { Almaraz (2002) }\end{array}$ & May 1941 \\
\hline Spain & Hospice de Viella & Silene vulgaris & Durrieu (1962); Almaraz (2002) & 12 Sept. 1961 \\
\hline Spain & Hospice de Viella & Silene vulgaris & Durrieu (1966); Almaraz (2002) & \\
\hline Sweden & Öland, Borgholm & Silene nutans & Lindeberg (1959) & "several collections" \\
\hline Sweden & Uppland, Norrtälje & Silene nutans & Lindeberg (1959) & \\
\hline Sweden & $\begin{array}{l}\text { Gotland, Visby, } \\
\text { below Galgberget }\end{array}$ & Silene nutans & Lindeberg (1959) & 14 June 1920 \\
\hline Sweden & $\begin{array}{l}\text { Öland, Högsrum } \\
\text { par., St Rör }\end{array}$ & Silene vulgaris & Lindeberg (1959) & \\
\hline Sweden & Gotland, Visby & Silene vulgaris & Lindeberg (1959) & 24 June 1895 \\
\hline Sweden & Öland, Glömminge & Silene vulgaris & Lindeberg (1959) & 13 July 1901 \\
\hline Sweden & Öland, Borgholm & Silene vulgaris & Lindeberg (1959) & 16 July 1915 \\
\hline Sweden & $\begin{array}{l}\text { Gotland, nr Visby, } \\
\text { Bingen mill ("ad molam } \\
\text { Bingen pr. Visby") }\end{array}$ & Silene vulgaris & $\begin{array}{l}\text { Eliasson (1933); } \\
\quad \text { Lindeberg (1959) }\end{array}$ & 15 July 1929 \\
\hline Switzerland & $\begin{array}{l}\text { Aostatal, Gressen, } \\
\text { Crête du Torrent }\end{array}$ & Silene latifolia & Zogg (1985) & Aug. 1979 \\
\hline Switzerland & $\begin{array}{l}\text { Puschlav } \\
\quad \text { (Poschiavo), Selva }\end{array}$ & Silene vulgaris & Zogg (1985) & Sept. 1905 \\
\hline Switzerland & Visperterminen & Silene vulgaris & Zogg (1985) & July 1911 \\
\hline Switzerland & Vergeletto & Silene vulgaris & Bär (1915) & $\leq 1915$ \\
\hline Switzerland & $\begin{array}{l}\text { Vernayaz (Martigny), } \\
\text { Les Marécottes }\end{array}$ & Silene vulgaris & $\begin{array}{l}\text { Mayor \& Viennot-Bourgin } \\
\quad(1960) \text {; Zogg (1985) }\end{array}$ & Aug. 1954 \\
\hline Ukraine & & Silene latifolia & Savchenko \& Heluta (2012) & \\
\hline
\end{tabular}

melandrii, but also could be a different species. Further specimens and DNA analysis are needed to assess whether $T$. melandrii is also found in the wild on further species.

\section{Discussion}

Thecaphora melandrii is seen to be a scarce species, with relatively few records, and is apparently restricted to Europe. It does, however, have quite a wide range, 


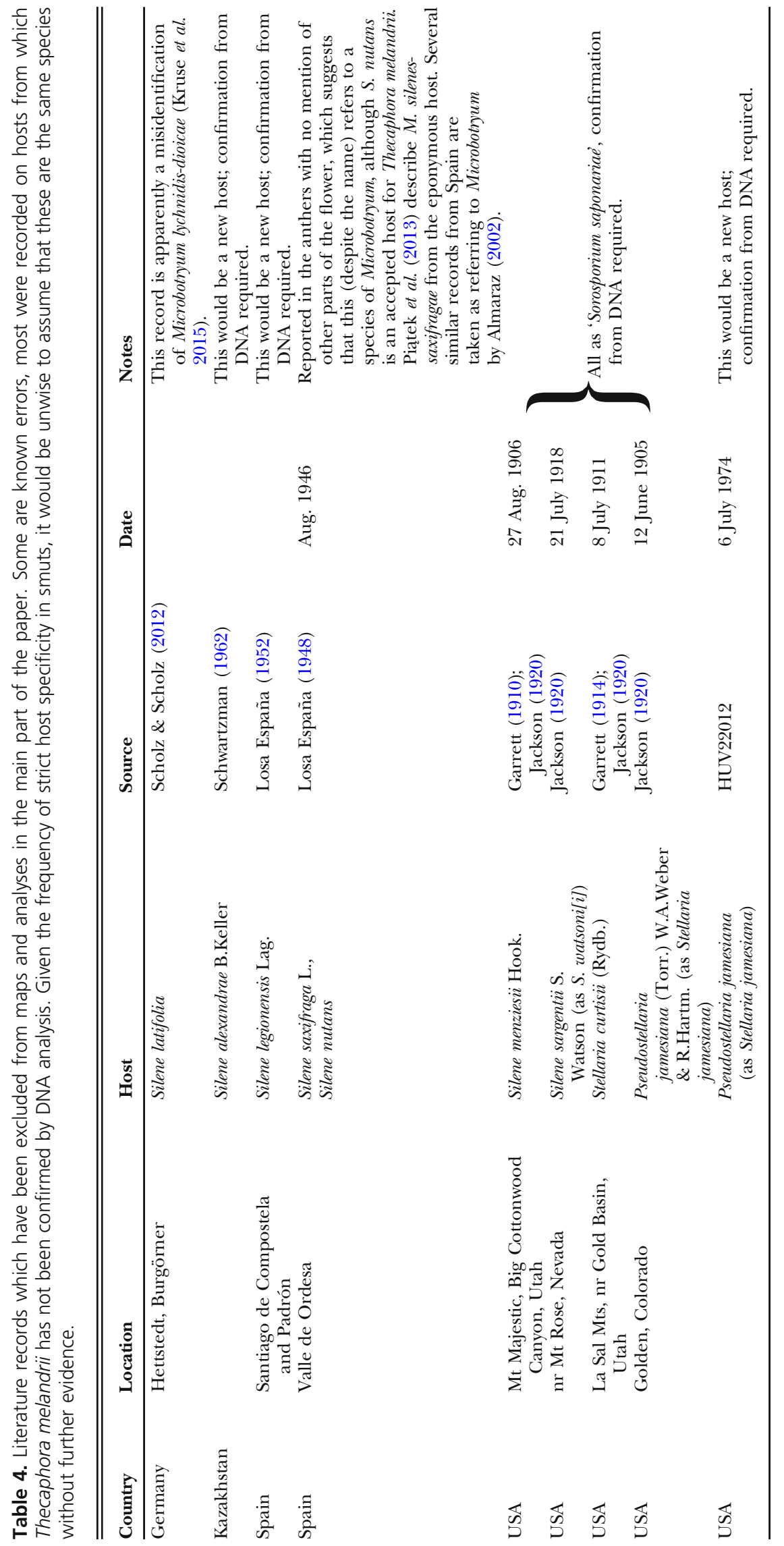




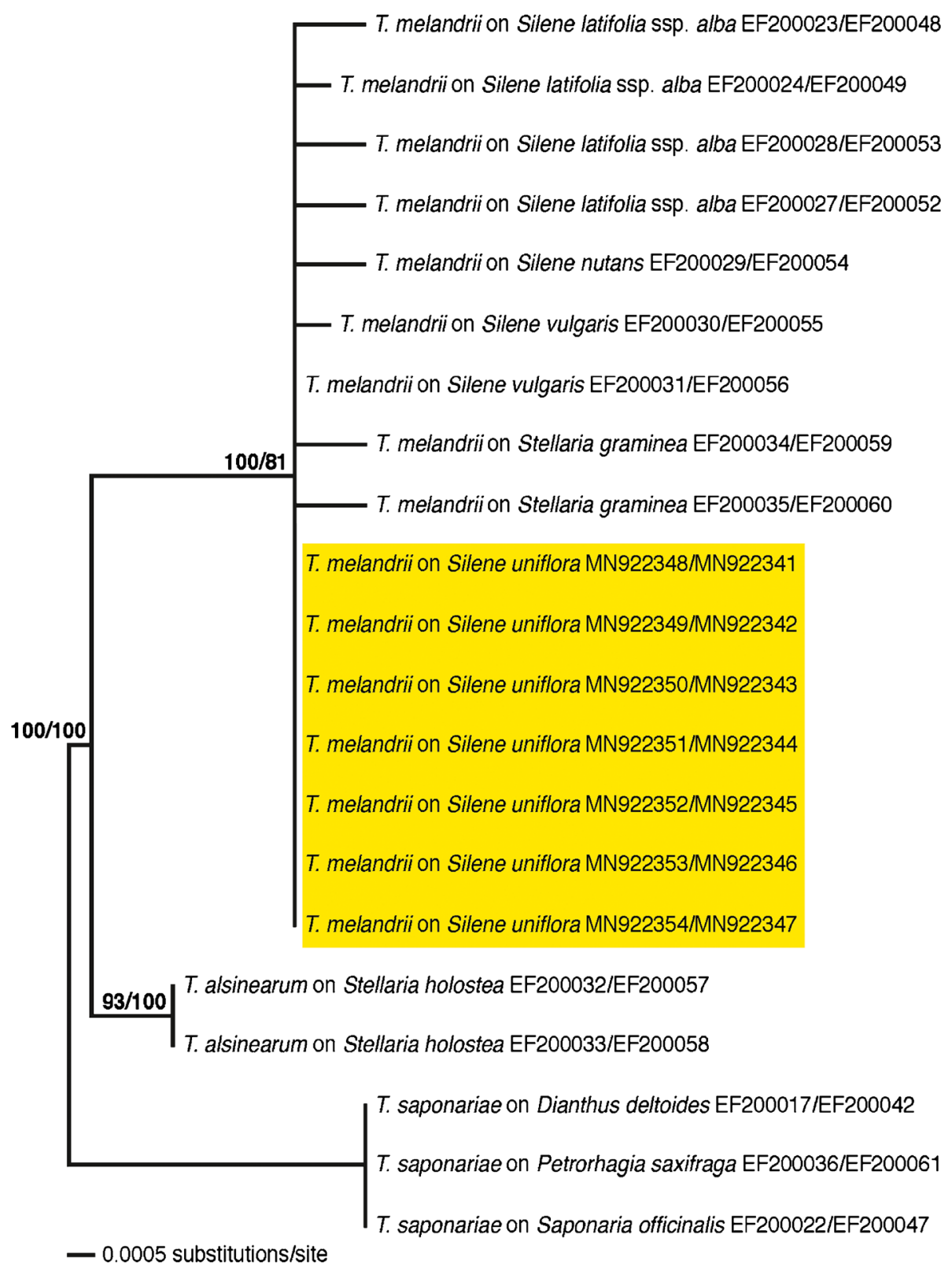

Fig. 4. Bayesian inference of phylogenetic relationships within the sampled Thecaphora specimens: see Phlylogenetic analyses under Materials and Methods for details. Numbers on branches before slashes are estimates for a posteriori probabilities, numbers on branches after slashes are ML bootstrap support values. Branch lengths were averaged over the sampled trees. They are scaled in terms of expected numbers of nucleotide substitutions per site. The specimens from England are highlighted in orange. T. = Thecaphora

particularly within central and eastern Europe, and here we demonstrate an extension of the known range to England. The ITS and $28 S$ regions of the genome show little variation, suggesting that $T$. melandrii is homogenous across this range. However, it has a wide host range including species in two genera within the Caryophyllaceae, and on quite distantly related species within the genus Silene. These conditions all suggest that it may be distributed more widely, both geographically and across hosts, and that further searching for this species would be valuable.
The coexistence of Thecaphora melandrii with species of Microbotryum is interesting; the T. melandrii infection is systemic and deforms the anthers (and other floral organs) in the host, presumably excluding plants from infection by Microbotryum spp. But it would be interesting to examine whether infection by Microbotryum spp. has any relation to subsequent infection by $T$. melandrii, and how these relations play out in a population over time. This would be a valuable supplement to the evidence for coexistence of different Microbotryum species on the same hosts in Abbate et al. (2018). 
Open Access This article is licensed under a Creative Commons Attribution 4.0 International License, which permits use, sharing, adaptation, distribution and reproduction in any medium or format, as long as you give appropriate credit to the original author(s) and the source, provide a link to the Creative Commons licence, and indicate if changes were made. The images or other third party material in this article are included in the article's Creative Commons licence, unless indicated otherwise in a credit line to the material. If material is not included in the article's Creative Commons licence and your intended use is not permitted by statutory regulation or exceeds the permitted use, you will need to obtain permission directly from the copyright holder. To view a copy of this licence, visit http://creativecommons.org/ licenses/by/4.0/.

\section{References}

Abbate, J. L., Gladieux, P., Hood, M. E., de Vienne, D. M., Antonovics, J., Snirc, A. \& Giraud, T. (2018). Co-occurrence among three divergent plantcastrating fungi in the same Silene host species. Molec. Ecol. 27: 3357 - 3370.

Almaraz, T. (2002). Bases corológicas de flora micológica Ibérica, números 1766 - 1932. Cuad. Trab. Fl. Micol. Ibér. 17: 1 - 124.

Bär, J. (1915). Die Flora des Val Onsernone. Part II: Verzeichnis der wildwachsenden Pflanzen und wichtigsten Kulturpflanzen und ihre Standorte. Mitt. Bot. Mus. Univ. Zürich 70: 5 - 413 [in German].

Béla, K. J. (1924). Növénytani repertórium. Bot. Közlem. 21: 80 - 99 [in Hungarian and Latin].

Chung, E., Petit, E., Antonovics, J., Pedersen, A. B. \& Hood, M. E. (2012). Variation in resistance to multiple pathogen species: anther smuts of Silene uniflora. Ecol. Evol. 2: 2304 - 2314.

Crous, P. W., Wingfield, M. J., Burgess, T. I., Hardy, G. E. St. J., Gené, J., Guarro, J., Baseia, I. G., García, D., Gusmão, L. F. P., Souza-Motta, C. M., Thangavel, R., Adamčík, S., Barili, A., Barnes, C. W., Bezerra, J. D. P., Bordallo, J. J., Cano-Lira, J. F., de Oliveira, R. J. V., Ercole, E., Hubka, V., Iturrieta-González, I., Kubátová, A., Martín, M. P., Moreau, P. A., Morte, A., Ordoñez, M. E., Rodríguez, A., Stchigel, A. M., Vizzini, A., Abdollahzadeh, J., Abreu, V. P., Adamčíková, K., Albuquerque, G. M. R., Alexandrova, A. V., Álvarez Duarte, E., Armstrong-Cho, C., Banniza, S., Barbosa, R. N., Bellanger, J. M., Bezerra, J. L., Cabral, T. S., Caboň, M., Caicedo, E., Cantillo, T., Carnegie, A. J., Carmo, L. T., Castañeda-Ruiz, R. F., Clement, C. R., Čmoková, A., Conceição, L. B., Cruz, R. H. S. F., Damm, U., da Silva, B. D. B., da Silva, G. A., da Silva, R. M. F., de Santiago, A. L. C. M., de Oliveira, L. F., de Souza, C. A. F., Déniel, F., Dima, B., Dong, G., Edwards, J., Félix, C. R., Fournier, J., Gibertoni, T. B., Hosaka, K., Iturriaga,
T., Jadan, M., Jany, J. L., Jurjević, Ž., Kolařík, M., Kušan, I., Landell, M. F., Leite Cordeiro, T. R., Lima, D. X., Loizides, M., Luo, S., Machado, A. R., Madrid, H., Magalhães, O. M. C., Marinho, P., Matočec, N., Mešić, A., Miller, A. N., Morozova, O. V., Neves, R. P., Nonaka, K., Nováková, A., Oberlies, N. H., Oliveira-Filho, J. R. C., Oliveira, T. G. L., Papp, V., Pereira, O. L., Perrone, G., Peterson, S. W., Pham, T. H. G., Raja, H. A., Raudabaugh, D. B., Řehulka, J., Rodríguez-Andrade, E., Saba, M., Schauflerová, A., Shivas, R. G., Simonini, G., Siqueira, J. P. Z., Sousa, J. O., Stajsic, V., Svetasheva, T., Tan, Y. P., Tkalčec, Z., Ullah, S., Valente, P., Valenzuela-Lopez, N., Abrinbana, M., Viana Marques, D. A., Wong, P. T. W., Xavier de Lima, V. \& Groenewald, J. Z. (2018). Fungal Planet description sheets: 716 - 784. Persoonia 40: 240 - 393.

Dauphin, P. (1993). Compte-rendu de l'excursion du 4 juillet 1993 dans le Blaylais. Bull. Soc. Linn. Bordeaux 21: 161 - 163 [in French].

Denchev, C. M. (2007a). Microbotryum lagerheimii sp. nov. (Microbotryaceae). Mycol. Balcanica 4: 61 - 67.

(2007b). Microbotryum savilei sp. nov. (Microbotryaceae). Mycol. Balcanica 4: 69 - 73.

\& Denchev, T. T. (2011). New records of smut fungi. 4. Microbotryum coronariae comb. nov.. Mycotaxon 118: 53 - 56.

Giraud, T. \& Hood, M. E. (2009). Three new species of anthericolous smut fungi on Caryophyllaceae. Mycol. Balcanica 6: $79-84$.

Denchev, T. T., Kemler, M., Begerow, D. \& Denchev, C. M. (2019). Molecular and morphological evidences reveal a new smut fungus, Microbotryum arcticum (Microbotryaceae), on Silene uralensis (Caryophyllaceae) from Greenland and Canada. Willdenowia 49: 241 - 255.

Durrieu, G. (1962). Contribution a l'étude de la microflore fongique des Pyrénées IV. Bull. Soc. Hist. Nat. Toulouse 97: 260 - 270 [in French].

(1966). Étude écologique de quelques groups de champignons parasites des plantes spontanées dans les Pyrénées. Bull. Soc. Hist. Nat. Toulouse 102: 7 277 [in French].

Eliasson, A. G. (1933). Svampar från Gotland och Öland. Svensk Bot. Tidskr. 23: 141 - 160 [in Swedish].

Garrett, A. O. (1910). The smuts and rusts of Utah. Mycologia 2: 265 - 304.

(1914). The smuts and rusts of Utah II. Mycologia 6: $240-258$.

Greenberg, A. K. \& Donoghue, M. J. (2011). Molecular systematics and character evolution in Caryophyllaceae. Taxon 60: 1637 - 1652.

Ivić, D., Sever, Z., Scheuer, C. \& Lutz, M. (2013). A checklist of smut fungi of Croatia. Mycotaxon 121: 499.

Jackson, H. S. (1920). New or noteworthy North American Ustilaginales. Mycologia 12: 149 - 156.

Jørstad, I. (1963). Ustilaginales of Norway (exclusive of Cintractia on Carex). Nytt Mag. Bot. 10: 85 - 130. 
Kemler, M., Denchev, T. T., Denchev, C. M., Begerow, D., Piątek, M. \& Lutz, M. (2020). Host preference and sorus location correlate with parasite phylogeny in the smut fungal genus Microbotryum (Basidiomycota, Microbotryales). Mycol. Progr. 19: 481 - 493.

Kruse, J., Kummer, V. \& Thiel, H. (2015). Bemerkenswerte Funde phytoparasitischer Kleinpilze (4). Z. Mykol. 81: 185 - 220 [in German]. , Shivas, R. G. \& Thines, M. (2018). The first smut fungus, Thecaphora anthemidis sp. nov. (Glomosporiaceae), described from Anthemis (Asteraceae). MycoKeys 41: 39 - 50.

Thiel, H., Brodtbeck, T., Ecker, H., Leb, C., Ostrow, H., Rätzel, S. \& Kummer, V. (2017). Bemerkenswerte Funde phytoparasitischer Kleinpilze (7). Z. Mykol. 83: 127 - 156 [in German]. , Thiel, H., Rätzel, S., Schmidt, A., Schreier, S., Simmat, U. \& Kummer, V. (2020). Bemerkenswerte Funde phytoparasitischer Kleinpilze (13). Z. Mykol. 86: 77 - 119 [in German].

Le Gac, M., Hood, M. E., Fournier, E. \& Giraud, T. (2007). Phylogenetic evidence of host-specific cryptic species in the anther smut fungus. Evolution 61: $15-26$.

Legon, N. W. \& Henrici, A. (2005). Checklist of the British and Irish basidiomycota. Royal Botanic Gardens: Kew (+updates available from https:// basidiochecklist.science.kew.org/).

Lind, J. (1913). Danish fungi as represented in the herbarium of E. Rostrup. Gyldendalske Boghandel/ Nordisk Forlag, Copenhagen.

Lindeberg, B. (1959). Ustilaginales of Sweden. Symb. Bot. Upsal. 16: 1 - 175.

Liro, J. I. (1938). Die Ustilagineen Finnlands II. Ann. Acad. Sci. Fenn., Ser. A 42: i - xiii \& 1 - 720 [in German].

Losa España, M. (1942). Aportación al estudio de la flora micológica española. Anales Jard. Bot. Madrid 2: 87 - 142 [in Spanish].

(1948). Micromicetos del Pirineo español. Anales Jard. Bot. Madrid 8: 297 - 338 [in Spanish].

(1952). Notas micológicas. Collect. Bot. (Barcelona) 3: 147 - 161 [in Spanish].

Lutz, M., Bauer, R., Begerow, D., Oberwinkler, F. \& Triebel, D. (2004). Tuberculina: rust relatives attack rusts. Mycologia 96: $614-626$.

Göker, M., Piątek, M., Kemler, M., Begerow, D. \& Oberwinkler, F. (2005). Anther smuts of Caryophyllaceae: molecular characters indicate host-dependent species delimitation. Mycol. Progr. 4: 225 - 238.

Piątek, M., Kemler, M., Chlebicki, A. \& Oberwinkler, F. (2008). Anther smuts of Caryophyllaceae: molecular analyses reveal further new species. Mycol. Res. 112: 1280 - 1296.

\& Vánky, K. (2009). An annotated checklist of smut fungi (Basidiomycota: Ustilaginomycotina and Microbotryales) in Slovenia. Lidia 7: 33 - 72.
Marsden-Jones, E. \& Turrill, W. B. (1957). The bladder campions (Silene maritima and $\mathrm{S}$. vulgaris). The Ray Society, London.

Mayor, E. \& Viennot-Bourgin, G. (1960). Contribution à l'étude de la flore du Valais. Bull. Murith. Soc. Valais. Sci. Nat. 77: $70-87$ [in French].

Niessen, J. (1937). Die Pflanzengallen (Phyto- und Zoocecidien) des Rheinlandes. Ein Verzeichnis mit kritischen Anmerkungen und Fundortsangaben. Erster Nachtrag. Decheniana 94: 252 - 280 [in German].

Örtel, G. (1886). Beiträge zur Flora der Rost- und Brandpilze (Uredineen und Ustilagineen) Thüringens [pro parte]. Deutsche Bot. Monatsschr. 4: 85 - 89 [in German].

Petrak, F. (1970). Schedae ad Cryptogamas exsiccatas editae a Museo Historiae Naturalis Vindobonensi. Ann. Naturhist. Mus. Wien 74: 521 - 531 [in German].

Piątek, M., Lutz, M., Ronikier, A., Kemler, M. \& Świderska-Burek, U. (2012). Microbotryum heliospermae, a new anther smut fungus parasitic on Heliosperma pusillum in the mountains of the European Alpine System. Fungal Biol. 116: 185 - 195.

\& Kemler, M. (2013). Microbotryum silenessaxifragae sp. nov. sporulating in the anthers of Silene saxifraga in southern European mountains. IMA Fungus 4: 29 - 40.

Wang, Y., Wang, S. R. \& Kellner, R. (in press). Thecaphora dahuangis, a new species causing leaf smut disease of the traditional medicinal plant "da-huang" (Rheum palmatum) in China. Pl. Pathol.

Refrégier, G., Le Gac, M., Jabbour, F., Widmer, A., Shykoff, J. A., Yockteng, R., Hood, M. E. \& Giraud, T. (2008). Cophylogeny of the anther smut fungi and their caryophyllaceous hosts: prevalence of host shifts and importance of delimiting parasite species for inferring cospeciation. BioMed Centr. Evol. Biol. 8: 100.

Rodwell, J. S., Pigott, C. D., Ratcliffe, D. A., Malloch, A. J. C., Birks, H. J. B., Proctor, M. C. F., Shimwell, D. W., Huntley, J. P., Radford, E., Wigginton, M. J. \& Wilkins, P. (2000). British plant communities. Volume 5: Maritime communities and vegetation of open habitats. Cambridge University Press, Cambridge.

Savchenko, K. C. \& Heluta, V. P. (2012). Smut fungi of Ukraine, a checklist. Sydowia 64: 281 - 300.

Săvulescu, T. (1957). Ustilaginalele din Republica Populară Romînă II. Editura Academiei Republicii Populare Romîne, Bucharest [in Romanian].

Scholz, H. \& Scholz, I. (2012). Die Brandpilze Deutschlands, 3. Nachtrag. Verh. Berliner Bot. Vereins 145: 161 - 217 [in German].

Schwartzman, S. R. [Шварцман, C.P.] (1962). Contributions to a microfungus flora of Kazakhstan [Материалы к истории микрофлоры Казахстана]. Publishing House of the Academy of Science of the Kazakh SSR, Alma-Ata [in Russian].

Smith, P. A., Lutz, M., Ziegler, R. \& Piątek, M. (2017). Anther smuts of Silene acaulis and S. uniflora in the 
Outer Hebrides, including an assessment of ITS genotypes of Microbotryum silenes-acaulis. IMA Fungus 8: 107 - 116.

Sydow, H. (1934). Novae fungorum species - XXII. Ann. Mycol. 32: 286 - 299 [in Latin and German].

Vánky, K. (2012). Smut Fungi of the World. American Phytopathological Society Press, St Paul, MN.

\& Lutz, M. (2007). Revision of some Thecaphora species (Ustilaginomycotina) on Caryophyllaceae. Mycol. Res. 111: 1207 - 1219.

, _ \& Bauer, R. (2008). About the genus Thecaphora (Glomosporiaceae) and its new synonyms. Mycol. Progr. 7: $31-39$.

Vasighzadeh, A., Zafari, D., Selçuk, F., Hüseyin, E., Kurşat, M., Lutz, M. \& Piątek, M. (2014). Discovery of Thecaphora schwarzmaniana on Rheum ribes in Iran and Turkey: implications for the diversity and phylogeny of leaf smuts on rhubarbs. Mycol. Progr. 13: $881-892$.

Ziegler, R., Lutz, M., Piątek, J. \& Piątek, M. (2018). Dismantling a complex of anther smuts (Microbotryum) on carnivorous plants in the genus Pinguicula. Mycologia 110: 361 - 374.

Zogg, H. (1985). Die Brandpilze Mitteleuropas. Cryptog. Helv. 16: 1 - 277 [in German].

\section{Publisher's Note}

Springer Nature remains neutral with regard to jurisdictional claims in published maps and institutional affiliations. 